\title{
MULTIMEDIA PEMBELAJARAN UNTUK PENINGKATAN KREATIVITAS MELUKIS DI TAMAN KANAK-KANAK
}

\author{
Eny Munisah *) \\ enimuni0@gmail.com \\ Pendidikan Bahasa Inggris \\ STKIP Muhammadiyah Kotabumi
}

\begin{abstract}
Multimedia learning is very near with visual communication. The visualization of concept which is given to the learner as the conbination of pictur, diagram, graph, draft, and chart should become one. Creativity is the origin, suitable, and functional. The origin and the suittable painting of kindergarten is periodic, typology, and other.Painting of kindergarden is a pra-chart periode, while typology is visual and non visual type the indication who seldom appear with painting of children is stereotype, tranparant, lying down, perpendicular, and finanity. There are three creatives personality, they are: 1). open with experience, 2). the ability to evaluate situation based on standars of personality, 3). the ability to do experiment to play with concept. The condition above is used as basic to improve the ability of kindergarten in peinting. They will play computer, painting, make a creative something if every person has three criterias above so he/she has a good psychology that will support to create a creative creation.
\end{abstract}

Key Word: Multimedia Learning, Creative Painting.

\section{Multimedia pembelajaran}

Multimeia pembelajaran di dalam From Wikipedia the free encyclopedia (2009;10) dikemukakan sebagai berikut: "Multimedia include combination of text, audia, stiil image, animation, vidio, and interactivity content form. Pengertian multimedia pembelajaran ini telah diartikan oleh Google-Koco. Utomo google dalam ensiklopedia bebas adalah "Penggunaan komputer untuk menyajikan dan menggabungkan teks, suara, gambar, animasi dan vidio dengan alat bantu (tool) dan koneksi. Pengertian multimedia yang lain dikemukakan oleh Ariesto Hadi Sutopo (2009:3). Ia mengatakan bahwa komputer multimedia adalah komputer yang mempunyai alat output seperti biasanya, yaitu alat disply dan hardcopy, dengan rekaman audio berkualitas tinggi, image berkualitas tinggi, animasi, dan rekaman vidio.

Media pembelajaran digunakan untuk memotivasi anak dalam melukis agar lebih kreatif dan sangat canggih, yaitu komputer. Dengan produk multimedia, anak TK dapat melukis sesuai dengan fantasinya. Munadhi (2008:150) mengemukakan bahwa 
kelebihan multimedia sebagai media pembelajaran, $\quad$ yaitu $1 \quad$ )mampu menampilkan objek sebenarnya tidak ada secara fisik atau dengan imagery; 2) mampu menggabungkan semua unsur; teks, vidio, animasi, image, grafik, dan sound menjadi integratif; 3) mengakomodasi peserta didik sesuai dengan modalitas belajar, dan bertipe visual, auditif, kinestik; 4) mampu mengembangkan materi pembelajaran terutara membaca dan mendengarkan secara mudah. Ciri multimedia, yaitu: berbasis komputer, interaktif dan individual.

Media pembelajaran merupakan salah satu komponen penting di dalam pembelajaran. Para guru hendaknya selalu memanfaatkan media dalam pembelajaran. Para guru hendaknya selalu memanfaatkan media dalam pembelajaran. Sebagaimana yang dikemukakan oleh Mustikasari (2009:134) bahwa media pmbelajaran sebagai berikut:

Meliputi alat bantu guru dalam mengajar serta sarana pembawa pesan dari sumber belajar ke penerima pesan (siswa). Sebagai penyaji dan penyalur pesan, media belajar dalam hal-hal tertentu bisa mewakili guru menyajikan informasi belajar kepada siswa. Jika program media itu didisain dan dikembangkan secara baik maka fungsi itu akan dapat diperankan oleh media meskipun tanpa keberadaan guru
Pengertian media pembelajaran yang lain dikemukakan oleh Akhmad Sudrajat, yaitu "segala sesuatu yang dapat menyalurkan pesan, dapat memotivasi pikiran, perasaan, dan kemauan pembelajar sehingga dapat memotivasi terciptanya proses belajar pada diri pembelajar".

Fungsi media pembelajaran, yaitu: 1) mengatasi keterbatasan siswa; 2) dapat melampaui batas ruang kelas, karena objek terlalu besar atau terlalu kecil, atau obyek berbahaya; 3) memungkinkan adanya interaksi langsung antara siswa dengan lingkungannya; 4) menghasilkan keseragaman pengamatan; 5) menanamkan konsep dasar yang benar, konkret, dan realistis; 6) membangkitkan keinginan dan minat baru; 7) membangkitkan motivasi pembelajar untuk belajar; 8) memberikan pengalaman yang integral dari yang konkret sampai dengan abstrak.

Jenis media pembelajaran, yaitu: 1) media visual meliputi grafik, diagram, chart, bagan, poster, kartun, dan komik; 2) media audio meliputi radio, tape recorder, laboratorium bahasa dan sejenisnya; 3) projection stiil media; slide, dan OHP; 4) projection motion media film: film, TV, vidio, komputer.

Multimedia pembelajaran yang dirancang sangat erat dengan disain komunikasi visual, visualisasi pesan konsep yang disampaikan ke pembelajar merupakan perpaduan dari gambar, sketsa, 
grafik, bagan, chart, harus menyatu dengan baik. Multimedia yang dikembangkan memenuhi persyaratan interaktif, artinya komputer digunakan untuk satu anak maka diperlukan untuk kontrol dengan keyboard, mouse, atau alat input lainnya. Dengan demikian pemakai dapat menggunakan dengan mudah.

\section{Aries Hadi Sutopo (2009:32)} membagi enam tahap pengembangan multimedia, yaitu: "concept, desaign, material colecting, assembling, testing, dan distribution"

1. Concept, menentukan tujuan termasuk identifikasi audiens, macam aplikasi, tujuan aplikasi, dan spesifikasi umum. Output berupa dokumen dengan penulisan yang bersifat naratif untuk mengungkapkan tujuan pengembangan nultimedia;

2. Design, membuat spesifikasi secara rinci mengenai arsitektur proyek. Design berbasis multimedia dikembangkan dari perancangan pembuatan film menggunakan storyboard, interaktif, dilengkapi dengan flowchart view;

3. Material colecting, merupakan tahap pengumpulan bahan berupa clipart, image, animasi, audio, grafik, foto, dan lai-lain yang diperlukan;

4. Assembling, merupakan tahap seluruh obyek multimedia dibuat;
5. Testing, tahap ini dilakukan setelah selesai tahap pembuatan multimedia, jika belum baik maka diperlukan revisi;

6. Distribution, merupakan tahap evaluasi, jika belum memenuhi kreteriia kelayakan, maka diadakan revisi senhingga multimedia layak digunakan.

Di dalam pengembangan multimedia sebagai media pembelajaran diperlukan tim yang profesional dan diperlukan waktu yang cukup lama. Lebih lanjut dijelaskan bahwa untuk merancang multimedia interaktif perlu diperhatikan beberapa kreteria penilaian sebagai berikut:

1. kriteria kemudahan navigasi. Sebuah program harus dirancang sesederhana mungkin sehingga pembelajar tidak perlu belajar komputer terlebih dahulu;

2. kriteria kandungan kognisi. Kandungan isi program harus memberikan pengelaman kognisi yang dibutuhkan pembelajar;

3. kriteria integrasi media, memberikan penekanan pada pengintegrasian berbagai ketrampilan berbahasa, mendengarkan, berbicara, menulis, dan membaca;

4. untuk menarik minat pembelajar, program harus mempunyai tampilan yang artistikdan estetik juga merupakan sebuah ceritera; 
5. kriteria penilaian yang terakhir adalah fungsi secara keseluruhan. (Munadhi, 2008:153).

Berdasarkan atas kelebihan yang dimiliki oleh multimedia di atas, di TK belum banyak dikembangkan maka sangat perlu dikembangkannya produk multimedia untuk meningkatkan kreativitas melukis. Pembelajaran dengan multimedia di TK ini merupakan high technology, diharapkan dapat menjadi sebuah inovasi di dalam pendidikan anak usia dini.

\section{Belajar dan Pembelajaran.}

\section{a. Teori Behavioristik.}

Menurut teori behavioristik yang dikemukakan oleh Thorndike,Watson, Clark Hull dkk. dalam Budiningsih (2009:20-21) belajar adalah perubahan tingkah laku sebagai akibat dari adanya interaksi antara stimulus dan respon. Dengan demikian, dapat dikatakan bahwa belajar merupakan bentuk perubahan yang dialami pembelajar dalam hal kemampuannya untuk bertingkah laku dengan cara baru sebagai hasil interaksi antara stimulus dan respon. Seseorang setelah belajar sesuatu dengan indikator bahwa audien dapat menunjukkan adanya perubahan perilakunya. Dalam teori behavioristik faktor masukan sangat penting berujud stimulus dan keluaran berujud respon. Faktor penguatan juga penting merupakan bagian dalam teori ini.
Terkait dengan penelitian dan pengembangan multimedia ini, anak TK perlu diberikan stimulus dalam bentuk multimedia CD pembelajaran.

Stimulus tersebut berupa contoh lukisan secara manual maupun komputer yang tersusun dari berbagai bentuk bidang geometris menjadi sebuah lukisan yang bercorak naif, dan langkah-langkah melukis. Dengan demikian, anak TK akan merespon sesuai dengan kemampuan fantasinya, sehingga anak dapat melukis kreatif.

\section{b. Teori Kontruktivisme}

Di dalam pembelajaran seni budaya menggunakan teori kontruktivisme sebagaimana dikemukakan oleh Martadi (2009:1) sebagai berikut:

Depdiknas (2010:5) yang mengutip pendapat Driver seperti yang dikutip Faser dan Walberg (2011:6) menciptakan prosedur pembelajaran seni budaya berdasarkan kontruktivisme dengan jalan memfasilitasi siswa membangun sendiri konsep-konsep baru tentang pengalaman seni berdasarkan konsep lama yang telah dimiliki.

Lebih lanjut Martadi (2009:6-7) menjelaskan bahwa teori kontruktivisme ini merupakan teori belajar yang menekankan pada pengalaman individual atau pengetahuan yang telah ada sebelumnya. Pembelajarannya tidak berpusat pada guru, namun berpusat pada pembelajar akan 
menyesuaikan informasi baru atau pengetahuan yang disampaikan guru dengan pengetahuan dan pengalaman yang telah dimiliki pembelajar. Teori ini sangat relevan dengan peningkatan kreativitas melukis anak TK, sebagaimana pernyataannya bahwa satu faktor yang sangat penting mempengaruhi proses belajar adalah apa yang telah diketahui pembelajar. Hal ini disebut prior knowledge atau pengetahuan dasar. Pengetahuan dasar ini akan menjadi dasar berpijak untuk menggabungkan berbagai unsur dilingkungannya menjadi struktur kognitif dalam aktivitas fisik maupun mental.

Sebagaimana dikemukakan oleh Budiningsih (2009:59) teori kontruktivisme ini guru mempunyai peranan kunci dalam interaksi pembelajaran adalah pengendalian, yang meliputi:

1. menumbuhkan kemandirian dengan menyediakan kesempatan untuk mengambil keputusan dan bertindak;

2. menumbuhkan kemampuan mengambil keputusan dan bertindak dengan meningkatkan pengetahuan dan ketrampilan siswa;

3. menyediakan sistimdukungan yang memberikan kemudahan belajar agar siswa mempunyai peluang optimal untuk berlatih.

Jika ditinjau dari sisi pendidikan lewat seni, dalam hal ini peningkatan kreativitas melukis anak TK sangat sesuai karena pembelajarannya berpusat pada pembelajar. Dengan demikian, maka seni digunakan sebagai peningkatan kreativitas. Sifat-sifat fantastis dan permainan yang menyatu dengan seni, memberikan kemungkinan kebebasan dalam bentuk ekspresinya. Seni mendidik disiplin, disiplin seni adalah disiplin yang membebaskan untuk berkreasi, sehingga anak menjadi kreatif.

Selanjutnya pengertian pembelajaran menurut Mukminan (2009:6), yaitu proses pengolahan lingkungan seseorang yang dengan sengaja dilakukan sehingga memungkinkan anak belajar untuk melakukan atau mempertunjukkan tingkah laku tertentu, sebagai respon terhadap situasi tertentu pula. Pembelajaran ini mempunyai prinsip: respon yang berakibat menyenangkan pembelajaran. Sesuai dengan sifat anak TK yang masih sangat dekat dengan belajar dan bermaim maka multimedia yang direncanakan sebagai media pembelajaran peningkatan kreativitas melukis sangat mendukung keberadaannya.

\section{Filsafat Seni.}

Para ahli filsafat seni telah banyak mengemukakan tentang sumber seni dan asalmula seni, di antaranya adalah penyair The Liang Gie (2010:28) mengemukakan asal mula seni, yaitu:

Dorongan batin untuk bermain-main yang ada dalam diri seseorang. Seni merupakan 
semacam permainan penyeimbangan segenap kemampuan mental manusia berhubung dengan adanya kelebihankelebihan energi yang harus disalurkan keluar, kelebihan tenaga ini lalu menciptakan kebutuhan dan kesempatan untuk melakukan rangkaian permainan yang imaginatif dan kegiatan hiburan yang akhirnya menghasilkan karya seni.

Lebih lanjut dijelaskan bahwa, teori kelahiran seni ini disebut Theory of play. Teori ini juga didukung oleh pengajar sejarah seni dari Jerman Konrad Lange yang mengatakan bahwa permainan adalah seni dari kanak-kanak. Hal ini sangat terkait dengan anak TK yang ada pada hakikatnya adalah belajar sangat dekat dengan bermain, permainan adalah seni dari kanak-kanak.

\section{Kreativitas.}

Untuk memahami kreativitas sering terjadi bentrokan dan penggabungan dari istilah-istilah kunci dan pandangan dunia yang mereka tunjukkan, sangat penting untuk memahami kreativitas dalam dunia modern. Untuk menggarirbawahi hal tersebut akan diatur perubahan urutan mendasar dalam pasangan-pasangan yang berkaitan. Perunahan-perubahan tersebut bersama-sama memuncak pada suatu pergantian yang mendasar dalam paradigma antara kreativitas yang dianggap sebagai kreasi (suatu aktivitas artistik yang dilaksanakan dengan orang-orang ternama untuk tujuan simbolis yang lebih formal atau kurang formal) dan kreativitas dianggap sebagai "penemuan" (suatu proses industri yang dilaksanakan oleh kolektivitas anonim untuk tujuan fungsional yang lebih praktis atau kurang praktis). Di dalam seni lukis, keaslian, kelayakan serta fungsional benar-benar diutamakan. Kemudian aspek fungsional di dalam seni lukis sangat terkait dengan aspek afektif, yaitu nilai dan sikap, untuk dinikmati keindahannya. Terkait dengan lukis kreatif menggunakan komputer di TK maka terdapat 3 hal yang sangat mendasar di dalam kreativitas, yaitu keaslian dan kelayakan dan fungsional. Keaslian dan kelayakan lukisan anak TK sangat terkait dengan periodisasi, tipologi dan berbagai gejala lukisan anak-anak. Lukisan anak TK termasuk periode pra bagan dan bagan, sedangkan tipologinya adalah tipe visual dan non visual. Gejala yang sering muncul pada lukisan anak-anak adalah stereotipe, tembus pandang, rebahan, tegak lurus garis dasar, finanitas.

Kreativitas dikemukakan oleh Sahman (2011:193) bahwa “jika proses kreatif itu melahirkan sesuatu yang baru atau orijinal maka proses ini dapat dilihat sebagai kreativitas" Pengertian kreativitas Britannica Cincise Encyclopedia dengan yang dikemukakan Humar Sahman ada kesamaan, yaitu tentang orijinal. Jika dilacak dari sisi sejarah bangsa Indonesia, nenek moyang kita sejak zaman pra sejarah 
telah menunjukkan adanya kretivitas. Hasil kreativitasnya dapat dilihat musium Sonobudoyo Yogjakarta, dan musium Nasional Jakarta. Mereka telah mampu menciptakan berbagai karya seni untuk mencukupi kebutuhan hidupnya, dan kebutuhan spiritualnya. Mereka telah melukis didinding, gua, mematung, mengukir, menganyam, cor logam,membangun. Karya seni ini merupakan buah tangan seniman yang didasari oleh olah rasa, olah cipta, olah pikir, dan olah karsa. Dengan demikian, para seniman telah berkreasi, berarti mereka mempunyai kreativitas yang tinggi.

Proses kreatif para seniman ini berkembang terus menerus sehingga dapat menemukan jati dirinya. Hal ini menunjukkan bahwa proses kreatif merupakan buah tangan para seniman yang berbeda-beda, terdiri dari sebuah runtutan imajinasi dan berbagai macam percobaan para seniman, akan mendapatkan suatu bentuk karya, tergantung oleh sifat bahannya. Contoh nyata pelukis Amri Yahya (bertaraf internasional) dari Yogyakarta telah bereksperimen melukis dengan berbagai bahan, pastel, cat air, cat minyak, acrilik, dan keramik. Namun, akhirnya kebanyakan lukisannya menggunakan kanvas dengan cat minyak dan acrilik, relatif akan lebih tahan lama. Berbeda dengan Rusli, melukis dari bahan kertas dan cat air, lukisannya kurang tahan lama. Warna-warna lukisan cat air akan lebih cepat pudar karena pengaruh sinar matahari. Proses kreatif lukisan Amri Yahya, banyak diilhami oleh lebak suasana perairan di daerah Palembang, asalnya. Proses kreatif lukisan Rusli banyak diilhami suasana alam yang beraneka ragam, pantai, keramaian kota, pasar hewan dan lain-lain. Tidak ketinggalan pelukis cilik dari Yogyakarta cukup eksis, dengan kemampuan kreativitasnya mereka melukis sehingga eksis.

Tabrani (2010:90) mengemukakan tentang ciri kreativitas antara lain: kepekaan, kelancaran, keluwesan, orisinalitas, elaborasi, redefinisi. Lebih lanjut dikemukakan bahwa cara berpikir anak adalah bagaikan dalam mimpi memungkinkan terjadinya proses kreasi. Apa yang dilukis anak, bukan semata apa yang dilihatnya, tetapi merupakan hasil kerjasama semua indera-inderanya yang anak rasakan dan imajinasikan serta cetusan jiwanya. Pada diri manusia terdapat adanya trio yaitu fisik-kreatif-rasio. Pada masa bayi tampak perkembangan kemampuan fisik, pada masa anak yang menonjol adalah kemampuan kreatif, pada masa remaja terjadi proses keseimbangan dinamis terpadunya ketiga kemampuan itu. Di dalam peningkatan kreativitas tidak terlepas dari kemampuan fisik dan rasio. Kreativitas meningkat apabila anak mencapai penghayatan, dan cukup ada 
kesulitan. Dengan demikian berikanlah kesempatan dan kehormatan pada anak agar dapat menemukan pemecahan masalah, maka ia akan kreatif. Disini juga orisinalitas ditekankan.

\section{Utami Munandar}

(2009:34) mengatakan bahwa terdapat tiga kondisi pribadi yang kreatif yaitu: 1) keterbukaan terhadap pengalaman, 2) kemampuan untuk menilai situasi sesuai dengan patokan pribadi seseorang, dan 3) kemampuan untuk bereksperimen, untuk bermain dengan konsep. Kondisi tersebut di atas sebagai dasar untuk peningkatan kreativitas melukis anak TK. Anak-anak TK akan bermain-main dengan komputer, melukis, menghasilkan suatu lukisan yang kreatif. Apabila setiap orang memiliki ketiga ciri tersebut, kesehatan psikologisnya sangat baik, akan mendorong menghasilkan karyakarya yang kreatif

\section{Selanjutnya Al-Khalili (2009:35)} mengatakan bahwa kreativitas anak, yaitu: kemampuan untuk menghasilkan pemikiran-pemikiran yang asli, tidak biasa, dan sangat fleksibel dalam merespon dan mengembangkan pemikiran dan aktivitas. Kreativitas ini juga dimiliki oleh mayoritas anak-anak. Akan tetapi kreativitas ini berbeda antara anak satu dengan lainnya, dan antara satu lingkungan dengan lingkungan lainnya. Karena itu kreativitas anak-anak sebenarnya adalah suatu pemikiran yang memiliki hasil cipta, bukan rutinitas atau sekedar mengikuti mode, kreativitas produktif. Maksud dari kreativitas produktif yaitu hasil produksi seni dan keilmuan yang diperoleh melalui usaha mendisiplinkan kecenderungan untuk bermain bebas, dan dengan nenentukan langkah-langkah untuk mencapai hasil yang sempurna.

Dengan dasar pengertian di atas, dapat dikatakan bahwa kreativitas melukis anak TK merupakan suatu pemikiran yang tidak rutin dan dimiliki hasil cipta yaitu lukisan. Salah satu fungsi jiwa adalah kreativitas menyangkut tiga demensi, yaitu proses, orang atau pribadi, dan produk kreatif. Dengan menggunakan proses kreatif sebagai kreteria kreativitas, maka segala produk yang dihasilkan dari proses itu dianggap sebagai produk kreatif, orangnya disebut sebagai orang yang kreatif. Dikatakan oleh Supriyadi (2012:23) bahwa ada lima pendekatan untuk mengukur kreativitas seseorang yaitu: analisis objektif terhadap produk kreatif, pertimbangan subjektif, inventori kepribadian, inventori biografis, dan tes kreativitas.

Analisis objektif terhadap produk kreatif hal ini relevan untuk mengukur peningkatan kreativitas melukis anak TK dengan multimedia. Indikator lukisan kreatif: orisinal, selalu berbeda-beda berarti kaya ide, bentuk maupun warna, dan fungsional. 


\section{Melukis Kreatif.}

Seni lukis adalah salah satu cabang seni rupa. Menurut Soedarso Sp. (2010:10) "Seni lukis adalah suatu pengucapan pengalaman artistik yang ditumpahkan dalam bidang dua demensional dengan menggunakan garis dan warna”. Kemudian orang yang sedang mengucapkan pengalaman artistik tersebut disebut melukis. Jika seorang melukis sesuatu dengan bentuk dan tema yang serba baru, seorang tersebut disebut melukis kreatif. Sebagaimana yang diungkapkan oleh Baker (2012:25) bahwa Painting activities also allow the studen to transfer ideas and impreeions of the word on to paper. Di sini jelaslah bahwa aktivitas melukis anak-anak selalu diijinkan memindahkan atau mengeuarkan gagasan-gagasannya dan kesan-kesan dari dunianya di atas kertas, atau bidang dua demensional.

Kegiatan melukis jika ditinjau dari sejarahnya nenek moyang dulu sudah cukup tua melakukannya. Nenek moyang bangsa Indonesia telah dapat melukis di dindingdinding batu gua, sejak Pra sejarah zaman batu tengah ribuan tahun sebelum Masehi. Pada zaman batu tengah disamping lukisan juga terdapat berbagai benda peninggalan berupa perkakas rumah tangga dari tulang, kulit kerang, tanduk. Berbagai peninggalan tersebut banyak dijumpai di kepulauan Indonesia bagian timur. Sebagai contoh menurut Van Heekeren lukisan di dinding batu gua Leang-leang Sulawesi Selatan berupa seekor babi hutan yang berlari. Lukisan ini dianggap mempunyai kekuatan magis. Hal ini terkait dengan kreativitas bahwa nenek moyang bangsa Indonesia sejak zaman Pra sejarah telah berkreasi melukis babi hutan sesuai dengan zaman dan kompetensinya.

Melukis bagi anak TK sangat erat dengan bermain. Sebagaimana ungkapan Affandi dan Dewobroto (2014:1) adalah "Dunia anak adalah dunia bermain. Dalam bermain anak menemukan kebebasan dan kegembiraan. Dengan bermain anak dapat mengembangkan daya fantasinya, dapat mencurahkan perasaan isi hatinya, dan dapat melatih ketrampilannya. Di dalam melukis, anak dapat mencurahkan segala gejolak jiwanya, sehingga anak mendapatkan suatu sublimasi. Jika gejolak jiwa anak tersebut tidak tersublimasi, anak akan mengalami tekanan jiwa. Apabila tekanan jiwa ini tidak tersalurkan dengan baik, bisa meledak dalam bentuk yang tidak terkontrol. Dengan demikian, melukislah salah satu media pencurahan isi jiwa anak yang dapat menghasilkan sebuah lukisan yang bermakna. Seni merupakan pencurahan isi jiwa manusia sehingga karyanya dapat dibaca dan dinikmati oleh orang lain. Orang lain tersebut menjadi haru, terkesan, dan senang karenanya. Pencurahan isi jiwa ini tidak hanya terdapat 
pada anak yang normal, tetapi juga terdapat pada anak yang cacat mata.

Kreativitas anak-anak dalam melukis telah diteliti oleh para ahli pendidikan, di antaranya adalah Victor Lowenfelf dalam Muharam Enton dan Warti Sundaryati (2010:35) sebagai berikut:

masa coreng-coreng : 2-4 tahun

masa pra-bagan

: 4-7 tahun

masa bagan

: 7-9 tahun

masa permulaan realisme

: 9-11 tahun

masa pseudo realisme

: 11-13 tahun

masa krisis puber

: 13-17 tahun

Dalam penelitian ini periodisasi yang relevan adalah masa prabagan, yaitu anak TK berumur 4-7 tahun. Pada masa ini anak sudah dapat mengendalikan tanggannya, garis yang dihasilkan tidak berupa corengan lagi, tetapi sudah mulai mendekati bentukbentuk yang berhubungan dengan dunia sekitarnya. Misalnya, bentuk manusia, rumah, hewan, dan lain-lain. Manusia dilukis berupa lingkaran kepala dengan dua garis ke bawah sebagai kakinya ditambah kedua tangan kanan dan kirinya. Masalah warna bebas tidak mempunyai hubungan tertentu dengan objek. Masalah ruang belum terpikirkan, sehingga anak melukiskan berbagai obyek sangat bebas tempatnya.

Lowenfelf (2008:53) menjelaskan lebih lanjut tentang seni anak-anak berbeda dengan seni orang dewasa sebagai berikut:
For the child, art is not same it is for the adult. Art for the child is merely ameans of expression. Since the child's thingking is deferen from that of the adullt, his expression must also be different. Out of this discrepancy between the adult's "taste" and the way in which a child expresses himself arise most of the difficulties and interferences in art teaching.

Pernyataan tersebut menjelaskan bahwa bagi anak, anggapan seni pada anak berbeda dengan orang dewasa. Seni bagi anak merupakan sebuah ekspresi. Pikiran anak berbeda dengan pikiran orang dewasa, tentu saja ekspresinya juga berbeda Ketidaksesuaian antara selera orang dewasa dengan bagaimana seorang anak mengekspresikan dirinya menjadikan kesulitan dan campur tangan tersendiri dalam pendidikan seni. Banyak di antara para guru yang ingin tahu tentang keindahan lukisan anak-anak, mereka meminta agar proporsi benar, warna yang bagus. Hal ini tidak sesuai dengan jiwa dan kehandak anak-anak. Mesti dibedakan antara seni anak-anak dan seni orang dewasa.

Analisis penulis bahwa peningkatan kreativitas melalui lukis komputer pada anak TK, merupakan salah satu dari bentuk sublimasi. Dengan adanya sublimasi ini akan tersalurkan segala gejolak jiwanya, sehingga anak akan tidak terbebani jiwanya. 
Jika berbagai gejolak jiwa ini tidak tersalurkan, maka akan berakibat pada perkembangan jiwa anak terganggu dan menjadi tidak harmonis kehidupannya. Mungkin anak akan murung, marah dan lesu.

Anak TK perlu dikenalkan komputer, hal ini akan menambah wawasan pengetahuannya (kognitif) sehingga mereka tidak gagap teknologi. Setelah dikenalkan berbagai komponen komputer sesuai dengan fungsinya maka lebih lanjut dikenalkan lukis komputer. Manakala lukis komputer ini dikenalkan maka anak akan bermain dengan warna dan bentuk yang sangat menyenangkan. Lukis komputer ini sangat praktis sebab segala peralatan telah tersedia, seperti pensil, kuas, warna, penghapus, kertas, anak tinggal memakainya. Tangan dan baju pun tidak kotor oleh cat. Dengan banyak kali berlatih lukis komputer, semakin banyak tersalurkan gejolak jiwanya sehingga anak akan merasa bebas dari tekanan, senang, segar, dan menghasilkan beberapa lukisan yang dapat menjadi kebanggaan mereka. Di sini aspek psikomotor akan terbina dengan baik. Lukisan mereka perlu dipajang dibagian ruang yang strategis. Hal ini akan menambah rasa senang dan bangga anak maupun orang tua, atau masyarakat di sekitarnya. Dengan demikian, akan terjadi peningkatan aspek apresiasi seni (afektif) di lingkungannya. Dengan demikian ketiga aspek yaitu kognitif, psikomotor, dan afektif akan terjalin dengan baik sehingga diharapkan dapat membantu perkembangan jiwa dan raga mereka menjadi harmonis, siap untuk meneruskan belajar di sekolah dasar.

\section{DAFTAR RUJUKAN}

Affandi \& Dowobroto 2014. Mengenal Seni Rupa Anak-anak. Yogjakarta: Gama Media

Budiningsih, Asri. 2009. Belajar dan Pembelajaran. Yogyakarta: Rineka Cipta.

Baker Leslie A. 2012, TheArt Teacher's Resourse Book. Reston: Publising Company.

Martadi. 2009. Pendekatan Kontruktivis dalam Pembelajaran Seni Budaya. Jurnal Pendidikan Seni Kagunan.

Muharam E. \& Warti S. 2010. Pendidikan Kesenian II Seni Rupa. Jakarta: Depdikbud.

Mukminan 2009, Desain Pembelajaran. Yogyakarta: Renika Cipta.

Mustikasari, Ardianti. 2009. Media Pembelajaran. Diambil pada tanggal 27 Desember 2018. dari http:edu-articles.com/mengenal-media pembelajaran.

Munadi, Yudhi. 2008. Media Pembelajaran. Cipayung-Ciputat: Gaung Persada. 
Sahman, Hamar. 2011. Mengenal Dunia Seni Rupa. Semarang: IKIP Semarang Press.

Soedarso Sp. 2010. Tinjauan Seni.Yogyakarta: Sakudayarsana.

Tabrani, Primadi. 2010. Memahami Cara Berpikir dan Bahasa Rupa Anak. Wacana Seni Rupa. Bandung: P3M-STISI.

The Liang Gie. 2010. Filsafat Seni Suatu Pengantar. Yogyakarta: CV Adipura. 